\title{
The Profitability Of The U.S. Food Supply Chain: Financial Indicators, Cross-Section And Time-Series Effects
}

Youshan Zhao, University of Florida, USA

Carlos O. Trejo-Pech, Universidad Panamericana at Guadalajara, Mexico Richard N. Weldon, University of Florida, USA

\begin{abstract}
This study examines the U.S. agribusiness' profitability from 1986 to 2008. By using regression analysis, we model accounting returns as a function of diverse financial indicators. To select the explanatory variables we further decompose the DuPont equation and perform some ad hoc transformations to model return on investment (rather than return on equity). In addition, using a two-way fixed effects model, we test within sectors and time effects of returns. We compare time effects with the three most recent economic recessions.
\end{abstract}

Keywords: US Agribusiness Profitability; US Food Supply Chain

\section{INTRODUCTION}

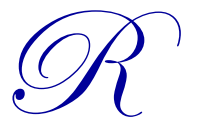

elatively recent research has examined various aspects of firm and industry financial performance for agricultural and food system (Neibergs, 1998; Schumacher \& Boland, 2005; Trejo-Pech, Weldon, \& House, 2008; Chaddad \& Mondelli, 2010). While the motivation for these studies varied, a common component on them was that performance was measured using accounting based measures of profitabilty. This study follows a similar approach. In particular, we decompose accounting returns of agribusinesses and test variability over time and across sectors.

To decompose accounting returns we use the DuPont equation as our main framework. The DuPont equation simply separates the return on equity into three parts, net margin, asset turnover, and leverage. After further decomposition of the DuPont equation and some transformations, we use regression analysis to study the financial indicators that affect the accounting return on investment for a sample of agribusiness over a twenty three years period. We also examine whether agribusiness' accounting returns vary across sectors within the U.S. food supply chain (e.g., test of cross-sectional effects). Finally, we test whether there is a time fixed effect in agribusiness' accounting returns. If any time effect exists in this sector, we investigate if there are coincidences with economic recessions.

The textbook or traditional DuPont equation has the return on equity $(R O E)$ as

ROE $=\frac{\text { Net Income }}{\text { Sales }} \times \frac{\text { Sales }}{\text { Total Assets }} \times \frac{\text { Total Assets }}{\text { Total Equity }}$.

$R O E$ measures the overall profitability of a firm, being a function of profit margin $(P M)$, asset turnover (ATO), and leverage. The first two components of equation 1 equal the return on assets or ROA (i.e., net income divided by total assets). ROA has been extensively used to examine historical performance and as measure for potentially predicting future 'operating' performance. In particular, the common form to analyze $R O A$ is performed by focusing on the return on net operating assets - measured as net operating income divided by net operating assets or total assets minus current liabilities. Selling \& Stickney (1989) use net operating income after taxes, while Fairfield \& Yohn (2003) use net operating income before taxes (and interest). Nissim \& Penman (2001) suggest a 
residual-income valuation framework that separates operating profitability from returns on financing activities. It is commonly believed that the firm's choice of capital structure can be manipulated. These studies isolate the leverage and associated returns as discretional attributes by management but not a desirable operating profitability variable. The motivation for this follows from Modigliani and Miller.

However, from equation 1 it is clear that the firm's level of leverage impacts profitability. Various factors associated with leverage; such as taxes, bankruptcy, or costs of financial distress influence the returns and profitability of the firm. Jensen (1989) argues that the costs of leverage, both direct and indirect, might improve performance by forcing management to pursue value-maximizing strategies to avoid debt pressure. For example, a firm with debt cost from borrowings might cut its underperforming production line more readily than a firm that bears no fixed debt cost. Other work shows that there is a positive relationship between financial condition and firm performance (Opler \& Sheridan, 1994). Thus, the financial structure captures the firm's ability to use available economic resources to increase profits. Considering the importance of leverage, in this study we decompose agribusinesses' accounting returns on the DuPont components and other underlying ratios.

With respect to agricultural sectors, the literature provides multiple explanations for the profitability measures. Forster (1996) analyses rates of return, solvency, liquidity and other financial ratio measurements in agribusinesses. Foster found that the capital structure and business risk of agribusiness are interrelated in determining accounting returns. In addition to the specific within firm financial factors mentioned above, there is an increasing interest regarding agribusiness profitability in response to macroeconomic conditions. Empirical results indicate that macroeconomic conditions (i.e. fiscal policy, business cycles) have differing effects on agribusiness profitability dependent on the firm's financial structure and market segment (Neibergs, 1998).

\section{DATA AND METHODOLOGY}

\section{Variables}

The overall approach of this study is based on the framework provided by the DuPont relationship provided in equation 1. However, the financial ratios for the empirical implementation are not exactly derived from the DuPont formula but are rather proxies of micro aspects of firms' operating and financial conditions. This "extended" DuPont methodology has ten financial ratios that serve as independent variables explaining agribusinesses profitability. ${ }^{1}$

To exclude the tax burden impact, which is independent of operating efficiency, we use in this study earnings before tax as proxy for net income. We decompose four underlying financial ratios as determinants of profit margin ( $P M$, the first component in equation 1). The profit margin function takes the following form:

$P M=f(G M, S G \& A, I N T, R \& D)$,

where $G M$ is gross margin, $S G \& A$ is selling, general and administrative expenses, $I N T$ is interest expenses, and $R \& D$ is research and development expenses. All indicators are divided by net sales.

The second component of equation 1, the asset turnover (ATO) ratio, measures the efficiency of a company's usage of assets in generating sales revenues. For an agribusiness, the major assets include accounts receivables; inventory; and property, plant and equipment. Thus, the asset turnover function is

$A T O=f(A R, I N V, P P \& E)$,

\footnotetext{
${ }^{1}$ We use the term "extended equation" to the version with ten ratios as elaborated below. We do not refer to the "extended equation" as used in some financial textbooks or practitioners financial reports (i.e., [Net Profit/Pretax Profit] x [Pretax Profit/EBIT] x [EBIT/Sales] x [Sales/Assets] x [Assets/Equity]).
} 
where $A R$ is accounts receivables turnover (net sales divided by average accounts receivables), INV is inventory turnover (cost of goods sold divided by average inventory), and $P P \& E$ is property, plant and equipment turnover (net sales divided by average property, plant and equipment).

The third part of the DuPont equation is leverage, which is defined in equation 2 as total assets divided by equity. From the basic accounting equation (total assets is equal to total equity plus debt), leverage can be transformed into total debt divided by total assets $(D / A)$. We prefer this transformation because financial debt proxies that involve equity in the denominator can be less stable than debt ratios scaled by total assets. Firms may experience drastic net income fluctuations that create problems in the calculation of equity used in financial ratios. For example, a current period large net loss might result in firm's retained earnings causing a negative or small positive equity balance. In addition, the market value of debt is more stable than the market value of equity. The function for $D / A$ is

$\frac{D}{A}=f(S T D, D C, L T D)$,

where $S T D$ is short-term borrowings to total assets, $C D^{2}$ is the current portion of long-term debt to assets, and LTD is long-term debt to assets.

Following the discussion above related to the variability of equity, instead of using equity we scale earnings before taxes by investments, defined as total assets minus current liabilities (i.e., liabilities without financial cost). Return on investment is thus defined as,

$R O I=\frac{\text { Earnings before taxes }}{\text { Total assets-current liabilites }}$.

$R O I$ is a relative more comprehensive measure of a firm's ability to generate returns to pay for its capital employed. While investment may be defined in a number of ways, we use net capital employed, which is the summation of fixed assets, other investments, and net working capital (equivalent to the denominator in equation 5).

\section{Model}

To test the linear relationship of the component ratios and the firm's return on investment, the ten underlying ratios are treated as independent variables. We assume that return on investment is non-randomly affected by both the cross-section and time-series. Because of the assumption that the cross-section and time-series effects are fixed, the models are essentially regression models with dummy variables that correspond to the specified effects. The two-way fixed effects regression model $^{3}$ is as follows:

$Y_{i t}=\alpha_{0}+\sum_{k}^{10} \beta_{k} X_{i t k}+\mu_{i}+v_{t}+\varepsilon_{i t}$,

where:

$Y_{\mathrm{it}}$ is $R O I$ of industry $i$ in year $t$,

$\alpha_{0}$ is the intercept coefficient of dropped dummy industry $i$ in the dropped year $t$,

$X_{\mathrm{it}}$ are the ten independent financial ratios of industry $i$ in the year $t$,

$\mu_{i}$ represents cross-section effects that are constant over time,

$v_{t}$ represents time effects that are common to all groups, and

$\varepsilon_{i t}$ is the residual error for industry $i$ in year $t$.

\footnotetext{
${ }^{2}$ Note that the current portion of long-term debt (CD) is presented separately from the both the short-term borrowing (STD )and the non-current portion of long-term debt (LTD). The reason that CD is separated STD is that these two types of debt have different interest rates and are representing different financing strategy of firm. The CD is separated from the LTD because it reflects the payment that is due within a year, which might be an element that pushes the management to take action to improve liquidity.

${ }^{3}$ This two-way fixed effects model is also refers to the two-way least square dummy variable model (two-way LSDV).
}

(C) 2013 The Clute Institute http://www.cluteinstitute.com/ 
This panel regression assumes that slopes are constant, only intercepts vary according to cross-section and time. This model specifies $i-1$ sector dummies, and $t-1$ time dummies to avoid perfect multicollinearity (Greene, 2012).

\section{Data}

Financial statement data for this study is from the Compustat database from Standard \& Poors. We filtered agribusinesses from Compustat based on the 3-digit SIC code as implemented in Trejo-Pech, Weldon, \& House, 2008. Two major industries and their thirteen sectors are assumed to make up the U.S. food supply chain. One major industry is agricultural wholesale and retail trade, referred to as food wholesale, retail, and service, or FWRS. The FWRS industry includes three sectors; retailers, food wholesalers, and food service (Table 1). The second industry is agricultural processing and marketing, referred to as food processing and beverage, or FPB. The FPB industry contains ten sectors (Table 2). The original sample contains 6,157 firm-year observations for the 19862008 time period. Eighty eight firms had missing values for major financial items and were removed from the sample. The final sample includes 6,069 firm-year observations, with $47 \%$ of the total observations belonging to the FPB, and $53 \%$ to the FWRS.

Table 1. Return on investment of the Food, Wholesale, and Retail Service (FWRS) industry by year and sector

\begin{tabular}{|c|c|c|c|c|}
\hline Year / Sector (SIC) & Retailers (540) & Food Wholesalers (514) & Food Service (581) & Mean \\
\hline 1986 & $14.1 \%$ & $12.5 \%$ & $7.2 \%$ & $11.3 \%$ \\
\hline 1987 & $16.8 \%$ & $11.8 \%$ & $11.0 \%$ & $13.2 \%$ \\
\hline 1988 & $11.3 \%$ & $9.9 \%$ & $10.9 \%$ & $10.7 \%$ \\
\hline 1989 & $10.3 \%$ & $10.7 \%$ & $9.1 \%$ & $10.0 \%$ \\
\hline 1990 & $12.5 \%$ & $-0.5 \%$ & $8.2 \%$ & $6.7 \%$ \\
\hline 1991 & $12.4 \%$ & $11.0 \%$ & $9.3 \%$ & $10.9 \%$ \\
\hline 1992 & $10.0 \%$ & $10.6 \%$ & $8.9 \%$ & $9.8 \%$ \\
\hline 1993 & $10.3 \%$ & $10.3 \%$ & $-3.9 \%$ & $5.6 \%$ \\
\hline 1994 & $9.1 \%$ & $10.9 \%$ & $11.2 \%$ & $10.4 \%$ \\
\hline 1995 & $12.0 \%$ & $10.7 \%$ & $8.4 \%$ & $10.4 \%$ \\
\hline 1996 & $11.9 \%$ & $9.5 \%$ & $8.4 \%$ & $9.9 \%$ \\
\hline 1997 & $11.5 \%$ & $9.8 \%$ & $7.4 \%$ & $9.5 \%$ \\
\hline 1998 & $10.5 \%$ & $0.8 \%$ & $14.3 \%$ & $8.5 \%$ \\
\hline 1999 & $11.5 \%$ & $9.7 \%$ & $11.9 \%$ & $11.0 \%$ \\
\hline 2000 & $8.2 \%$ & $7.5 \%$ & $13.8 \%$ & $9.8 \%$ \\
\hline 2001 & $8.3 \%$ & $16.5 \%$ & $13.1 \%$ & $12.6 \%$ \\
\hline 2002 & $6.3 \%$ & $24.4 \%$ & $11.8 \%$ & $14.2 \%$ \\
\hline 2003 & $4.0 \%$ & $24.2 \%$ & $11.1 \%$ & $13.1 \%$ \\
\hline 2004 & $2.5 \%$ & $25.1 \%$ & $12.6 \%$ & $13.4 \%$ \\
\hline 2005 & $6.7 \%$ & $25.5 \%$ & $14.1 \%$ & $15.4 \%$ \\
\hline 2006 & $9.6 \%$ & $20.4 \%$ & $15.1 \%$ & $15.0 \%$ \\
\hline 2007 & $10.9 \%$ & $22.5 \%$ & $15.3 \%$ & $16.2 \%$ \\
\hline 2008 & $5.2 \%$ & $25.0 \%$ & $12.6 \%$ & $14.3 \%$ \\
\hline Mean & $9.8 \%$ & $13.9 \%$ & $10.5 \%$ & $11.4 \%$ \\
\hline Std Dev & $3.3 \%$ & $7.6 \%$ & $4.0 \%$ & $2.7 \%$ \\
\hline
\end{tabular}

For any industry, over time, new firms enter while distressed firms leave. In addition, during the past couple decades many agribusiness firms were merged or acquired. This causes the panel data used in this study to be variable and unbalanced. Given that the purpose of this study is to explore the sectors effects and time effect on the sectors' return on investment for the FPB and FWRS industries as opposed to the individual firms', the weighted mean of financial ratios to measure the industry's primary financial condition is a better proxy of industry performance. In our model, net sales is used to calculate the weighted average ${ }^{4}$ of the financial ratios.

\footnotetext{
${ }^{4}$ The majority of past research employs the arithmetic mean of financial ratios as proxy of industry performance. But the straight average value does not reflect the industry objectively since it assumes that all firms have equal influence on that industry. In a competitive market, large firms tend to achieve economies of scale to gain competitive advantage. Emphasizing the resource efficiencies, productivity, and product quality, large firms dominate the development of industries. This can be justified because even though an industry may have many market players of all sizes, the market share is usually dominated by a single large firm or a few large firms.
} 
Table 2. Return on investment of the Food Processing and Beverage (FPB) industry by year and sector

\begin{tabular}{|c|c|c|c|c|c|c|c|c|c|c|c|}
\hline Sector & Meat & Diary & CFP F \& V & Grain mill & Bakery & S \& C & F \& O & Beverage & Misc. food & Tobacco & Mean \\
\hline SIC & 201 & $202^{\circ}$ & 203 & 204 & 205 & 206 & 207 & 208 & 209 & 210 & \\
\hline 1986 & $15.9 \%$ & $21.9 \%$ & $18.4 \%$ & $25.0 \%$ & $15.5 \%$ & $18.3 \%$ & $13.4 \%$ & $14.7 \%$ & $12.4 \%$ & $21.3 \%$ & $17.7 \%$ \\
\hline 1987 & $14.6 \%$ & $19.8 \%$ & $21.2 \%$ & $29.6 \%$ & $14.8 \%$ & $42.9 \%$ & $15.1 \%$ & $17.2 \%$ & $15.2 \%$ & $24.8 \%$ & $21.5 \%$ \\
\hline 1988 & $11.9 \%$ & $24.1 \%$ & $20.5 \%$ & $25.2 \%$ & $17.7 \%$ & $24.1 \%$ & $16.2 \%$ & $18.8 \%$ & $11.5 \%$ & $15.0 \%$ & $18.5 \%$ \\
\hline 1989 & $9.9 \%$ & $20.3 \%$ & $18.1 \%$ & $22.0 \%$ & $18.7 \%$ & $24.6 \%$ & $17.1 \%$ & $17.5 \%$ & $14.1 \%$ & $13.8 \%$ & $17.6 \%$ \\
\hline 1990 & $12.8 \%$ & $19.4 \%$ & $18.0 \%$ & $24.5 \%$ & $16.3 \%$ & $24.8 \%$ & $17.0 \%$ & $18.1 \%$ & $15.3 \%$ & $15.4 \%$ & $18.2 \%$ \\
\hline 1991 & $7.6 \%$ & $16.6 \%$ & $23.4 \%$ & $25.0 \%$ & $9.1 \%$ & $21.3 \%$ & $14.1 \%$ & $18.0 \%$ & $16.8 \%$ & $15.7 \%$ & $16.7 \%$ \\
\hline 1992 & $9.6 \%$ & $13.4 \%$ & $21.5 \%$ & $23.9 \%$ & $9.5 \%$ & $20.0 \%$ & $12.7 \%$ & $18.9 \%$ & $16.8 \%$ & $18.7 \%$ & $16.5 \%$ \\
\hline 1993 & $12.0 \%$ & $13.4 \%$ & $18.8 \%$ & $21.8 \%$ & $4.8 \%$ & $22.4 \%$ & $10.6 \%$ & $19.6 \%$ & $14.6 \%$ & $13.8 \%$ & $15.2 \%$ \\
\hline 1994 & $17.1 \%$ & $12.1 \%$ & $20.8 \%$ & $21.5 \%$ & $6.5 \%$ & $21.3 \%$ & $9.7 \%$ & $20.8 \%$ & $9.1 \%$ & $17.8 \%$ & $15.7 \%$ \\
\hline 1995 & $19.0 \%$ & $-4.8 \%$ & $20.1 \%$ & $30.7 \%$ & $7.5 \%$ & $21.2 \%$ & $14.5 \%$ & $19.9 \%$ & $12.7 \%$ & $20.1 \%$ & $16.1 \%$ \\
\hline 1996 & $11.8 \%$ & $12.1 \%$ & $29.5 \%$ & $21.2 \%$ & $4.8 \%$ & $21.9 \%$ & $11.9 \%$ & $19.0 \%$ & $6.9 \%$ & $23.5 \%$ & $16.3 \%$ \\
\hline 1997 & $8.8 \%$ & $10.3 \%$ & $19.6 \%$ & $8.8 \%$ & $6.7 \%$ & $28.2 \%$ & $7.1 \%$ & $21.7 \%$ & $13.8 \%$ & $22.3 \%$ & $14.7 \%$ \\
\hline 1998 & $11.3 \%$ & $5.2 \%$ & $20.1 \%$ & $20.1 \%$ & $3.0 \%$ & $20.3 \%$ & $6.0 \%$ & $18.5 \%$ & $16.3 \%$ & $18.2 \%$ & $13.9 \%$ \\
\hline 1999 & $15.1 \%$ & $9.1 \%$ & $25.1 \%$ & $24.4 \%$ & $6.6 \%$ & $25.7 \%$ & $3.7 \%$ & $16.5 \%$ & $17.6 \%$ & $21.7 \%$ & $16.6 \%$ \\
\hline 2000 & $10.6 \%$ & $8.1 \%$ & $21.4 \%$ & $24.9 \%$ & $9.0 \%$ & $19.7 \%$ & $2.9 \%$ & $15.2 \%$ & $24.3 \%$ & $19.5 \%$ & $15.6 \%$ \\
\hline 2001 & $8.3 \%$ & $4.1 \%$ & $24.8 \%$ & $9.5 \%$ & $6.5 \%$ & $19.8 \%$ & $3.7 \%$ & $18.8 \%$ & $20.2 \%$ & $16.9 \%$ & $13.3 \%$ \\
\hline 2002 & $6.1 \%$ & $8.7 \%$ & $17.6 \%$ & $11.8 \%$ & $4.0 \%$ & $21.6 \%$ & $7.1 \%$ & $18.7 \%$ & $18.9 \%$ & $19.3 \%$ & $13.4 \%$ \\
\hline 2003 & $7.6 \%$ & $9.9 \%$ & $19.5 \%$ & $12.6 \%$ & $1.2 \%$ & $15.9 \%$ & $5.7 \%$ & $16.3 \%$ & $18.5 \%$ & $12.8 \%$ & $12.0 \%$ \\
\hline 2004 & $11.3 \%$ & $7.1 \%$ & $16.3 \%$ & $13.8 \%$ & $13.4 \%$ & $17.0 \%$ & $5.9 \%$ & $17.7 \%$ & $17.1 \%$ & $15.8 \%$ & $13.6 \%$ \\
\hline 2005 & $10.6 \%$ & $6.0 \%$ & $14.2 \%$ & $10.6 \%$ & $14.1 \%$ & $17.1 \%$ & $11.6 \%$ & $17.2 \%$ & $22.8 \%$ & $16.7 \%$ & $14.1 \%$ \\
\hline 2006 & $1.1 \%$ & $9.7 \%$ & $16.1 \%$ & $11.1 \%$ & $15.5 \%$ & $16.9 \%$ & $13.0 \%$ & $16.8 \%$ & $12.1 \%$ & $17.6 \%$ & $13.0 \%$ \\
\hline 2007 & $6.6 \%$ & $7.5 \%$ & $16.3 \%$ & $13.6 \%$ & $17.1 \%$ & $12.5 \%$ & $19.5 \%$ & $18.6 \%$ & $14.2 \%$ & $20.1 \%$ & $14.6 \%$ \\
\hline 2008 & $-9.2 \%$ & $5.1 \%$ & $15.2 \%$ & $12.5 \%$ & $15.5 \%$ & $9.2 \%$ & $13.4 \%$ & $9.6 \%$ & $12.7 \%$ & $31.4 \%$ & $11.5 \%$ \\
\hline Mean & $10.0 \%$ & $11.3 \%$ & $19.9 \%$ & $19.3 \%$ & $10.3 \%$ & $21.2 \%$ & $11.0 \%$ & $17.7 \%$ & $15.4 \%$ & $18.8 \%$ & $15.5 \%$ \\
\hline Std Dev & $5.8 \%$ & $6.8 \%$ & $3.5 \%$ & $6.8 \%$ & $5.4 \%$ & $6.4 \%$ & $4.8 \%$ & $2.4 \%$ & $4.0 \%$ & $4.2 \%$ & $2.3 \%$ \\
\hline
\end{tabular}

CFP F \& V, stands for canned, frozen, and preserved fruits and vegetables; F\&O for Fats and Oil; and S\&G, for Sugar and Confectionary.

After computing sectors averages by the weighted method indicated above, there are 299 (or $13 \times 23$ ) sector-year samples in the data set. Each variable in each sector is calculated as an average value yearly. By industries, there are 230 and 69 computed means in FRB and FWRS respectively after taking the weighted average by net sales. The unbalanced firm-year panel data is transformed into a balanced sector-year panel data.

\section{Summary Statistics}

Summary statistics for the dependent variable are provided by industry groups in Tables 1 and 2 based on 3-digit SIC sectors. Mean and standard deviation of the ten explanatory financial ratios for all sectors in the two industries of food supply chain are shown by pooled years in Table 3 .

The average return on investment for the FWRS industry over past 23 years was $11.4 \%$ with a standard deviation of $2.7 \%$. From the three sectors, the food wholesaling has the highest return level, $13.9 \%$, followed by food services with $10.5 \%$, and finally the food retail sector with $9.8 \%$. The food wholesale sector is the most variable while food retail sector is relatively stable.

In the FPB industry, all ten sectors have average returns on investment higher than $10 \%$. The average return on investment of the entire FPB during the past 23 years is $15.5 \%$ with a standard deviation of $2.3 \%$. This accounting return for the FPB is $4.1 \%$ higher than that of the FWRS. Among the ten sectors of FPB, sugar and confectionery is the most profitable with an average return of $21.2 \%$. Three sectors, meat, bakery, fats and oils, have returns below $11 \%$. There appears to be little correlation between the average and the standard deviation across sectors.

Table 3 provides the mean and standard deviation of the ten explanatory financial variables for all sectors among the food supply chain over the 23 years. Overall, in terms of gross margin, the FPB industry outperforms the FWRS with $36.5 \%$ (standard deviation of $3.6 \%$ ) compared to $22.1 \%(2.2 \%)$. The sectors with the highest gross 
margins in the food supply chain are tobacco, beverages, bakery and sugar and confectionery, all belong to the FPB industry. Also, FPB operates more "aggressively" than FWRS by spending a larger portion of net sales on SG\&A expenses, interests, and R\&D expenditures. From the perspective of assets usage efficiency, companies with low profit margins usually tend to have high asset turnover. This is true in the food supply chain as well. FWRS has higher assets turnover rates than FPB. For instance, accounts receivable turnover in the FWRS industry (33.9) is 2.97 times higher than FPB (11.4). This is because the trading and services industry deal with final customers. Similarly, the inventory turnover in FWRS (18.8) is 2.83 times faster than in the FPB industry (6.6). The same happens for PP\&E turnover, the FWRS industry requires less manufacturing equipment. The above indicates that the FWRS has by far higher assets usage efficiency in generating sales.

Table 3. Summary statistics of explanatory variables

\begin{tabular}{|c|c|c|c|c|c|c|c|c|c|c|c|}
\hline Explanatory Variables & SIC & GM & INT & SG\&A & R\&D & $\mathbf{A R}$ & INV & PP\&E & STD & CD & LTD \\
\hline \multicolumn{12}{|c|}{ Panel A Food Processing and Beverage (FPB) } \\
\hline FPB & & $\begin{array}{l}36.5 \% \\
(3.6 \%)\end{array}$ & $\begin{array}{c}2.0 \% \\
(0.6 \%)\end{array}$ & $\begin{array}{l}22.4 \% \\
(3.0 \%)\end{array}$ & $\begin{array}{c}0.4 \% \\
(0.2 \%)\end{array}$ & $\begin{array}{c}11.4 \\
(1.49)\end{array}$ & $\begin{array}{c}6.6 \\
(1.39)\end{array}$ & $\begin{array}{c}4.2 \\
(0.75)\end{array}$ & $\begin{array}{l}1.6 \% \\
(2.4 \%)\end{array}$ & $\begin{array}{c}6.3 \% \\
(3.2 \%)\end{array}$ & $\begin{array}{l}24.2 \% \\
(6.0 \%)\end{array}$ \\
\hline Meat & 201 & $\begin{array}{l}11.9 \% \\
(1.8 \%)\end{array}$ & $\begin{array}{l}1.0 \% \\
(0.2 \%)\end{array}$ & $\begin{array}{c}6.5 \% \\
(0.9 \%)\end{array}$ & $\begin{array}{c}0.0 \% \\
(0.0 \%)\end{array}$ & $\begin{array}{c}18.9 \\
(2.29)\end{array}$ & $\begin{array}{l}11.3 \\
(2.66)\end{array}$ & $\begin{array}{c}6.7 \\
(1.43)\end{array}$ & $\begin{array}{l}1.6 \% \\
(2.5 \%)\end{array}$ & $\begin{array}{l}4.4 \% \\
(2.4 \%)\end{array}$ & $\begin{array}{l}26.1 \% \\
(3.5 \%)\end{array}$ \\
\hline Diary & 202 & $\begin{array}{l}26.3 \% \\
(1.5 \%)\end{array}$ & $\begin{array}{c}1.5 \% \\
(0.6 \%)\end{array}$ & $\begin{array}{l}18.1 \% \\
(1.3 \%)\end{array}$ & $\begin{array}{c}0.0 \% \\
(0.0 \%)\end{array}$ & $\begin{array}{c}12.2 \\
(0.95)\end{array}$ & $\begin{array}{l}12.5 \\
(2.5)\end{array}$ & $\begin{array}{c}5.3 \\
(0.58)\end{array}$ & $\begin{array}{c}0.4 \% \\
(0.7 \%)\end{array}$ & $\begin{array}{l}3.4 \% \\
(2.2 \%)\end{array}$ & $\begin{array}{c}32.0 \% \\
(13.6 \%)\end{array}$ \\
\hline C.F, and PF and V & 203 & $\begin{array}{l}39.2 \% \\
(3.1 \%)\end{array}$ & $\begin{array}{c}2.3 \% \\
(0.4 \%)\end{array}$ & $\begin{array}{l}22.6 \% \\
(2.2 \%)\end{array}$ & $\begin{array}{c}0.5 \% \\
(0.1 \%)\end{array}$ & $\begin{array}{c}9.8 \\
(1.15)\end{array}$ & $\begin{array}{c}4.3 \\
(0.22)\end{array}$ & $\begin{array}{c}3.8 \\
(0.48)\end{array}$ & $\begin{array}{c}3.7 \% \\
(3.8 \%)\end{array}$ & $\begin{array}{l}10.0 \% \\
(4.2 \%)\end{array}$ & $\begin{array}{l}27.0 \% \\
(8.1 \%)\end{array}$ \\
\hline Grain mill & 204 & $\begin{array}{c}39.7 \% \\
(10.4 \%)\end{array}$ & $\begin{array}{c}2.1 \% \\
(0.5 \%)\end{array}$ & $\begin{array}{l}25.7 \% \\
(8.7 \%)\end{array}$ & $\begin{array}{c}0.8 \% \\
(0.2 \%)\end{array}$ & $\begin{array}{c}11.5 \\
(0.93)\end{array}$ & $\begin{array}{c}6.3 \\
(0.56)\end{array}$ & $\begin{array}{c}3.8 \\
(0.88)\end{array}$ & $\begin{array}{l}2.6 \% \\
(3.5 \%)\end{array}$ & $\begin{array}{l}9.7 \% \\
(2.8 \%)\end{array}$ & $\begin{array}{l}25.3 \% \\
(4.2 \%)\end{array}$ \\
\hline Bakery & 205 & $\begin{array}{l}48.6 \% \\
(3.6 \%)\end{array}$ & $\begin{array}{c}2.6 \% \\
(2.2 \%)\end{array}$ & $\begin{array}{l}34.6 \% \\
(5.6 \%)\end{array}$ & $\begin{array}{c}0.2 \% \\
(0.4 \%)\end{array}$ & $\begin{array}{l}11.8 \\
(2.6)\end{array}$ & $\begin{array}{c}7.4 \\
(4.44)\end{array}$ & $\begin{array}{c}3.3 \\
(0.45)\end{array}$ & $\begin{array}{c}0.5 \% \\
(0.8 \%)\end{array}$ & $\begin{array}{c}3.3 \% \\
(3.8 \%)\end{array}$ & $\begin{array}{c}22.5 \% \\
(11.1 \%)\end{array}$ \\
\hline Suga & 206 & $\begin{array}{l}44.3 \% \\
(4.5 \%)\end{array}$ & $\begin{array}{c}2.1 \% \\
(0.5 \%)\end{array}$ & $\begin{array}{l}28 . \\
(2.2\end{array}$ & $\begin{array}{c}0.5 \% \\
(0.2 \%)\end{array}$ & $\begin{array}{c}8.6 \\
(1.13)\end{array}$ & $\begin{array}{c}4.6 \\
(0.38)\end{array}$ & $\begin{array}{c}3.5 \\
(0.34)\end{array}$ & $\begin{array}{c}0.6 \% \\
(0.7 \%)\end{array}$ & $\begin{array}{c}9.2 \% \\
(3.7 \%)\end{array}$ & $\begin{array}{l}16.5 \% \\
(4.2 \%)\end{array}$ \\
\hline Fats and oils & 207 & $\begin{array}{l}11.9 \% \\
(2.6 \%)\end{array}$ & $\begin{array}{l}1.6 \% \\
(0.6 \%)\end{array}$ & $\begin{array}{l}3.4 \% \\
(0.8 \%)\end{array}$ & $\begin{array}{c}0.1 \% \\
(0.0 \%)\end{array}$ & $\begin{array}{c}10.8 \\
(2.49)\end{array}$ & $\begin{array}{c}7.4 \\
(1.26)\end{array}$ & $\begin{array}{c}4.5 \\
(1.91)\end{array}$ & $\begin{array}{c}0.6 \% \\
(0.8 \%)\end{array}$ & $\begin{array}{c}4.2 \% \\
(4.2 \%)\end{array}$ & $\begin{array}{l}19.8 \% \\
(3.0 \%)\end{array}$ \\
\hline Beve & 208 & $\begin{array}{l}51.0 \% \\
(2.0 \%)\end{array}$ & $\begin{array}{l}2.7 \% \\
(0.4 \%)\end{array}$ & $\begin{array}{l}31.5 \% \\
(2.2 \%)\end{array}$ & $\begin{array}{c}0.3 \% \\
(0.1 \%)\end{array}$ & $\begin{array}{c}9.3 \\
(1.05)\end{array}$ & $\begin{array}{c}5.6 \\
(0.83)\end{array}$ & $\begin{array}{l}2.7 \\
(0.2)\end{array}$ & $\begin{array}{l}1.4 \% \\
(2.0 \%)\end{array}$ & $\begin{array}{l}6.9 \% \\
(2.1 \%)\end{array}$ & $\begin{array}{l}24.3 \% \\
(2.1 \%)\end{array}$ \\
\hline Misc.food kindred & 209 & $\begin{array}{l}40.3 \% \\
(2.7 \%)\end{array}$ & $\begin{array}{l}2.1 \% \\
(0.4 \%)\end{array}$ & $\begin{array}{l}27.4 \% \\
(1.9 \%)\end{array}$ & $\begin{array}{c}0.8 \% \\
(0.3 \%)\end{array}$ & $\begin{array}{c}8.8 \\
(1.02)\end{array}$ & $\begin{array}{c}4.0 \\
(0.51)\end{array}$ & $\begin{array}{c}4.1 \\
(0.72)\end{array}$ & $\begin{array}{l}1.4 \% \\
(3.3 \%)\end{array}$ & $\begin{array}{l}7.0 \% \\
(4.2 \%)\end{array}$ & $\begin{array}{l}22.4 \% \\
(3.2 \%)\end{array}$ \\
\hline Tob: & 210 & $\begin{array}{l}51.7 \% \\
(3.5 \%)\end{array}$ & $\begin{array}{c}2.6 \% \\
(0.7 \%)\end{array}$ & $\begin{array}{l}26.3 \% \\
(4.2 \%)\end{array}$ & $\begin{array}{c}0.9 \% \\
(0.3 \%)\end{array}$ & $\begin{array}{c}12.6 \\
(1.28)\end{array}$ & $\begin{array}{c}2.9 \\
(0.55)\end{array}$ & $\begin{array}{c}4.3 \\
(0.5)\end{array}$ & $\begin{array}{l}2.7 \% \\
(5.9 \%)\end{array}$ & $\begin{array}{c}4.7 \% \\
(2.1 \%)\end{array}$ & $\begin{array}{l}25.9 \% \\
(6.7 \%)\end{array}$ \\
\hline \multicolumn{12}{|c|}{ Panel B Food Wholesale, Retail, and Service (FWRS) } \\
\hline FWRS & & $\begin{array}{l}22.1 \% \\
(2.2 \%)\end{array}$ & $\begin{array}{c}1.5 \% \\
(0.5 \%)\end{array}$ & $\begin{array}{l}13.6 \% \\
(1.5 \%)\end{array}$ & $\begin{array}{c}0.0 \% \\
(0.0 \%)\end{array}$ & $\begin{array}{c}33.9 \\
(8.39)\end{array}$ & $\begin{array}{c}18.8 \\
(1.83)\end{array}$ & $\begin{array}{c}7.8 \\
(1.12)\end{array}$ & $\begin{array}{l}0.7 \% \\
(0.9 \%)\end{array}$ & $\begin{array}{c}4.3 \% \\
(1.8 \%)\end{array}$ & $\begin{array}{l}\text { 30.5\% } \\
(5.4 \%)\end{array}$ \\
\hline Food wholesalers & 514 & $\begin{array}{l}14.9 \% \\
(2.9 \%)\end{array}$ & $\begin{array}{c}0.6 \% \\
(0.2 \%)\end{array}$ & $\begin{array}{l}11.0 \% \\
(2.0 \%)\end{array}$ & $\begin{array}{c}0.0 \% \\
(0.0 \%)\end{array}$ & $\begin{array}{l}19.1 \\
(3.1)\end{array}$ & $\begin{array}{c}14.5 \\
(1.17)\end{array}$ & $\begin{array}{l}15.6 \\
(1.9)\end{array}$ & $\begin{array}{l}1.1 \% \\
(1.6 \%)\end{array}$ & $\begin{array}{l}3.4 \% \\
(1.6 \%)\end{array}$ & $\begin{array}{l}25.3 \% \\
(5.9 \%)\end{array}$ \\
\hline Food store-retail & 540 & $\begin{array}{l}25.4 \% \\
(1.6 \%)\end{array}$ & $\begin{array}{c}1.1 \% \\
(0.2 \%)\end{array}$ & $\begin{array}{l}20.1 \% \\
(1.1 \%)\end{array}$ & $\begin{array}{c}0.0 \% \\
(0.0 \%)\end{array}$ & $\begin{array}{c}52.7 \\
(15.35)\end{array}$ & $\begin{array}{c}10.0 \\
(0.74)\end{array}$ & $\begin{array}{c}6.3 \\
(1.25)\end{array}$ & $\begin{array}{c}0.5 \% \\
(0.8 \%)\end{array}$ & $\begin{array}{c}5.8 \% \\
(2.6 \%)\end{array}$ & $\begin{array}{l}33.5 \% \\
(5.4 \%)\end{array}$ \\
\hline Food service & 581 & $\begin{array}{l}25.9 \% \\
(2.2 \%)\end{array}$ & $\begin{array}{c}2.6 \% \\
(1.0 \%)\end{array}$ & $\begin{array}{c}9.8 \% \\
(1.3 \%)\end{array}$ & $\begin{array}{c}0.0 \% \\
(0.0 \%)\end{array}$ & $\begin{array}{c}29.9 \\
(6.72)\end{array}$ & $\begin{array}{c}31.8 \\
(3.58)\end{array}$ & $\begin{array}{c}1.7 \\
(0.22)\end{array}$ & $\begin{array}{c}0.4 \% \\
(0.5 \%)\end{array}$ & $\begin{array}{l}3.6 \% \\
(1.3 \%)\end{array}$ & $\begin{array}{l}32.6 \% \\
(5.0 \%)\end{array}$ \\
\hline Total food supply chain & & $\begin{array}{l}29.3 \% \\
(2.9 \%)\end{array}$ & $\begin{array}{c}1.7 \% \\
(0.6 \%)\end{array}$ & $\begin{array}{l}18.0 \% \\
(2.2 \%)\end{array}$ & $\begin{array}{c}0.2 \% \\
(0.1 \%)\end{array}$ & $\begin{array}{c}22.7 \\
(4.94)\end{array}$ & $\begin{array}{c}12.7 \\
(1.61)\end{array}$ & $\begin{array}{c}6.0 \\
(0.94)\end{array}$ & $\begin{array}{l}1.1 \% \\
(1.7 \%)\end{array}$ & $\begin{array}{c}5.3 \% \\
(2.5 \%)\end{array}$ & $\begin{array}{l}27.3 \% \\
(5.7 \%)\end{array}$ \\
\hline
\end{tabular}

Table 3 provides means and standard deviation (in parenthesis). GM is gross margin; $S G \& A$ is selling, general and administrative expenses to sales; INT is interest expenses to sales; $R \& D$ is research and development expenses to sales; $A R$ is accounts receivables turnover; $I N V$ is inventory turnover; $P P \& E$ is property, plant and equipment turnover; $S T D$ is short-term borrowings to total assets; $C D$ is the current portion of long-term debt to assets; and $L T D$ is long-term debt to assets.

One might expect that an economic recession would negatively affect accounting returns of industries. During the twenty three years covered in this study, according to the National Bureau of Economic Research (www.nber.org/cycles) the U.S. went through three economic recessions: July 1990-March 1991, March 2001 November 2001, and December 2007 - still in progress as of 2011. The years which included a significant part of these three recessions are in bold in Tables 1 and 2. Inspection of returns before and after recessions in the FWRS industry does not allow us to conclude. For example, for the retailer sector, returns during both the 1990-1991 and 2001 recessions exceed the pre- and post-recession returns, but show a substantial decrease in 2008 relative to 2007. 
The food wholesale sector exhibited a sharp decrease in returns in 1990, a sharp increase during the 2001 recession, and a minor increase in 2008. In general, there are sectors that experienced decreases on returns during a particular recession (e.g., meat in 2008, grain mill in 2001, and beverages in 2008), but had increases in returns during the other economic recession years. These trends indicate that other factors are more important in determining variation in accounting returns. Accounting return on investment might be more sensitive to management's strategies than to business cycles.

\section{RESULTS}

The results of the two-way fixed effects panel regression for equation 6 are presented in Tables 4 through 9 . Tables 4 and 5 present the results for the analysis of the financial ratios effect on firm accounting returns for the FPB and FWRS industries, respectively. Tables 6 and 7 present the results for the cross-section and time effects for the FPB industry, while Table 8 and 9 provide results the FWRS industry.

Table 4. Two-way fixed effects regression results for FPB industry

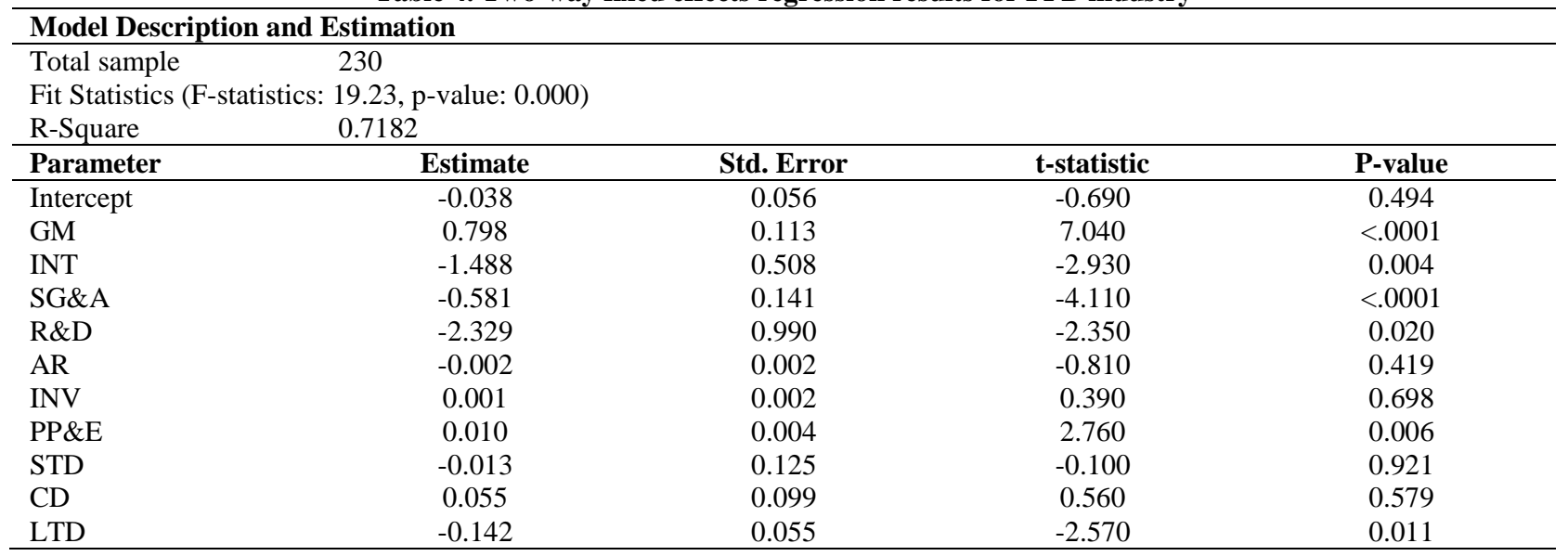

\section{Financial ratios}

The proposed relationship between accounting returns and the set of financial ratios in the FPB industry is statistically reliable (e.g., R square of 0.7182 and joint statistical significance at $1 \%$ ). However, no all ratios are statistically significant. The proxies $G M, I N T, S G \& A$ and $R \& D$ have the right signs (i.e., positive for margins and negative for expenditures) and are all statistically significant at the 5\% level. It is worth noting that R\&D in the food processing and beverage sector has not been effectively increasing contemporaneous profitability, which can be attributed to the lagged effect of research and development expenditures.

The second financial component tested is the significance of assets turnover. For this, there are three ratios; $A R, I N V$ and $P P \& E$. Only $P P \& E$ (net sales/ average PP\&E) with a value of 0.01 is statistically significant at the $1 \%$ level. Probably returns in $t$ are not affected by the level of assets turnover as the DuPont equation predicts, but rather but the change from $t-1$ to $t$, which represents the improvement in asset usage efficiency.

The final component of the DuPont expansion is leverage. The long term debt to assets ratio (LTD) is statistically significant, while the other two are not. $L T D$ has a coefficient of -0.142 , an inverse relationship with accounting returns. One percent increase in long term debt results in a decrease in ROI by 0.142 percent.

The results for the FWRS industry are provided in Table 5. The regression model with respect to the FWRS has an R square of 0.795 and F-statistics of 9.77 (p-value of 0.00). As with the FPB industry the GM, INT, and $S G \& A$ ratios have the right signs; gross margin is significant at $15 \%$, interest expense over sales is significant at $5 \%$. For all the remaining ratios only long term debt to assets is statistically significant at $5 \%$ level. Debt load is significantly affecting the profitability of FWRS (and FPB) inversely. One percent increase in the LTD/A ratio will result in a decrease in accounting return by $-0.56 \%$ and one percent increase in interest expense per dollar of sales will decrease return by $-4.46 \%$. 
Table 5. Two-way fixed effects regression results for FWRS industry

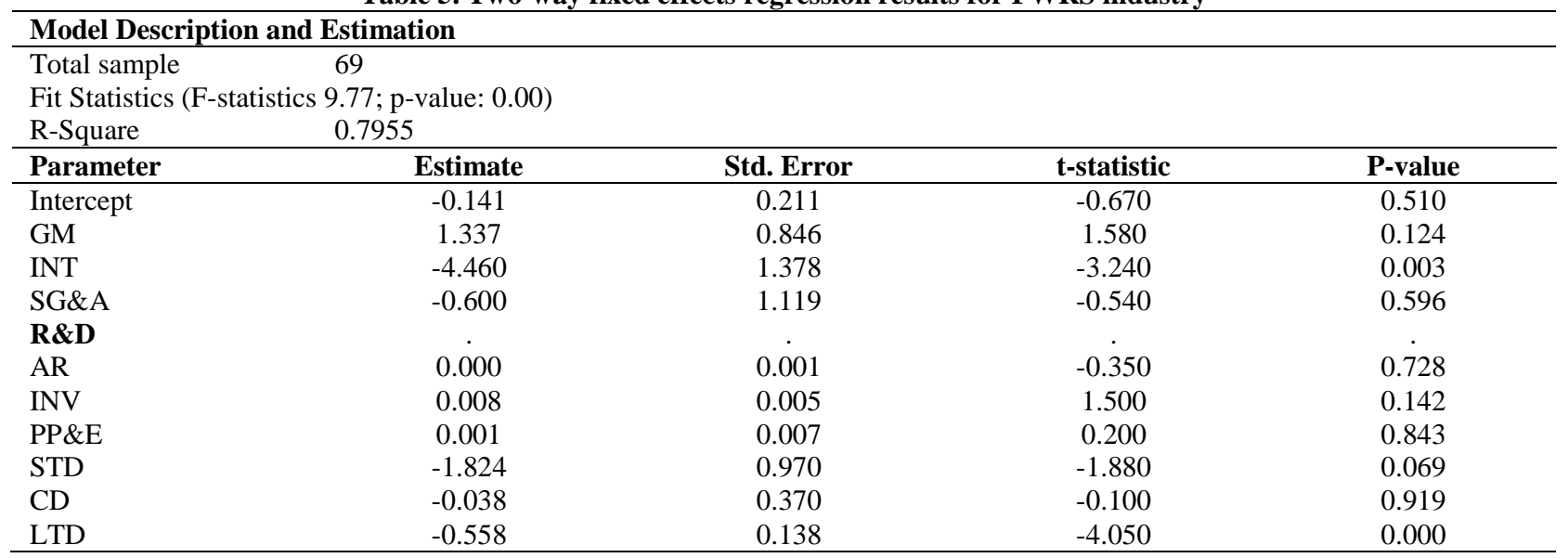

In summary, accounting returns (i.e., returns on investment) are affected by financial indicators according to the DuPont extended decomposition and the ad hoc transformations we modeled. The model explains at least $70 \%$ of variation (e.g., adjusted R square), and most estimated parameters have the right sign. While the expected signs of profit margins factors seem obvious and probably worthless to be modeled, signs and magnitudes of asset turnover and leverage are more an empirical problem, especially the latter. The traditional DuPont equation (1) shows that leverage should increase the return on equity, but cannot predict the effect on return on investment. Empirically, according to our model, long-term debt -but no short-term debt, negatively affects return on investment of agribusinesses.

\section{Cross-section and time effects}

The two-way fixed effect panel model is constructed to test for cross-sectional and time effects at the same time. The null hypotheses for these tests are that the parameters of sectors and time dummies are zero, there are no effects. It is a twofold test. The first stage jointly tests both the cross sectional and time effects. To explore the detail of fixed effects, two separate one-way fixed effect regressions are developed regarding the sector difference and time impact, respectively. It looks first at the sector effects which are assumed constant over time. In this study, this effect refers to the within differences of the component sectors in the FPB and FWRS. The second test aims to capture the differences over 23 years that is common to all component sectors in the U.S. food supply chain and to explore whether the time effect pattern follows the recent three economic recessions.

The basic output of the two-way fixed-effects model for the FPB industry is given in Table 6. In Panel A, the ten cross sections refer to the 3-digit SIC code that starts with 201 and ends with the tobacco sector with SIC code 210. The 23 time observations cover the 1986-2008 period. The F-test for the joint fixed effects is 5.15, significant at $1 \%$. Panel B provides the results of the two separate effect tests. There are both sector and time effects, statistically significant at $1 \%$ level.

Table 7 presents the two-way fixed effects regression results for the FPB industry. ${ }^{5}$ The parameter estimate of sector tobacco in year 2008 is the intercept (-0.038), a reference point. The other dummy parameter coefficients can be computed using this reference point as follows: intercept plus sector dummy coefficient plus year dummy coefficient. For example, the actual intercept of meat sector $(201)$ in year 2007 is $0.043(-0.038+0.06+0.021)$. Thus, holding other explanatory variables constant, the accounting return of the meat sector in 2007 is 0.081 $(0.06+0.021)$ higher than the tobacco sector in 2008.

\footnotetext{
${ }^{5}$ SAS sorts the dummy variables by an ascending order and drop the last cross-section dummy and time dummy automatically. The 230 regression equations $(23 \times 10)$ can be drawn on the combinations of ten sectors and 23 years. The two-way fixed effect panel regression model assumes that independent variables have constant slopes, only intercepts vary according to cross-section and time.
} 
Table 6. Tests for fixed cross-section and time effects in the FPB industry

\begin{tabular}{|c|c|c|c|c|}
\hline \multicolumn{5}{|c|}{ Panel A : Fixed effects test } \\
\hline Model & Fixed effect & Sample Size & F Test & Prob value \\
\hline Two-way & $\begin{array}{l}\text { Both sectors and time: } \\
\mathrm{i}=201,202,203 \ldots, 210 \\
\mathrm{t}=1986,1987,1988 \ldots \ldots, 2008\end{array}$ & 230 & $\mathrm{~F}(31,186)=5.15$ & $<.0001$ \\
\hline \multicolumn{5}{|c|}{ Panel B: Separate test for individual effect } \\
\hline Model & Fixed effect & Sample Size & F Test & Prob value \\
\hline One-way & Single sectors effect & 230 & $\mathrm{~F}(9,208)=9.21$ & $<.0001$ \\
\hline One-way & Single time effect & 230 & $\mathrm{~F}(22,195)=2.82$ & $<.0001$ \\
\hline
\end{tabular}

Examining the parameters in Table 7, six of the cross-sections are statistically different from the tobacco sector, the reference: meat; canned, frozen, and preserved fruits and vegetables (CFP F \& V), grain mill, sugar and confectionary, fats and oils, and miscellaneous food. A significant influence of sector-specific factors is present in the FPB industry. Inspection of the time effects shows that in eleven of the first fourteen years the time effects are statistically significant at $5 \%$ while none of the last eight years are significant. The time effects pattern do not match with the three economic recessions during the observation range. Thus, while time effects exist, there is no clear evidence to indicate a strong relationship between the years of the recession and the time effects, in terms of profitability.

Table 7. Parameter estimates in the fixed effects model for the FPB

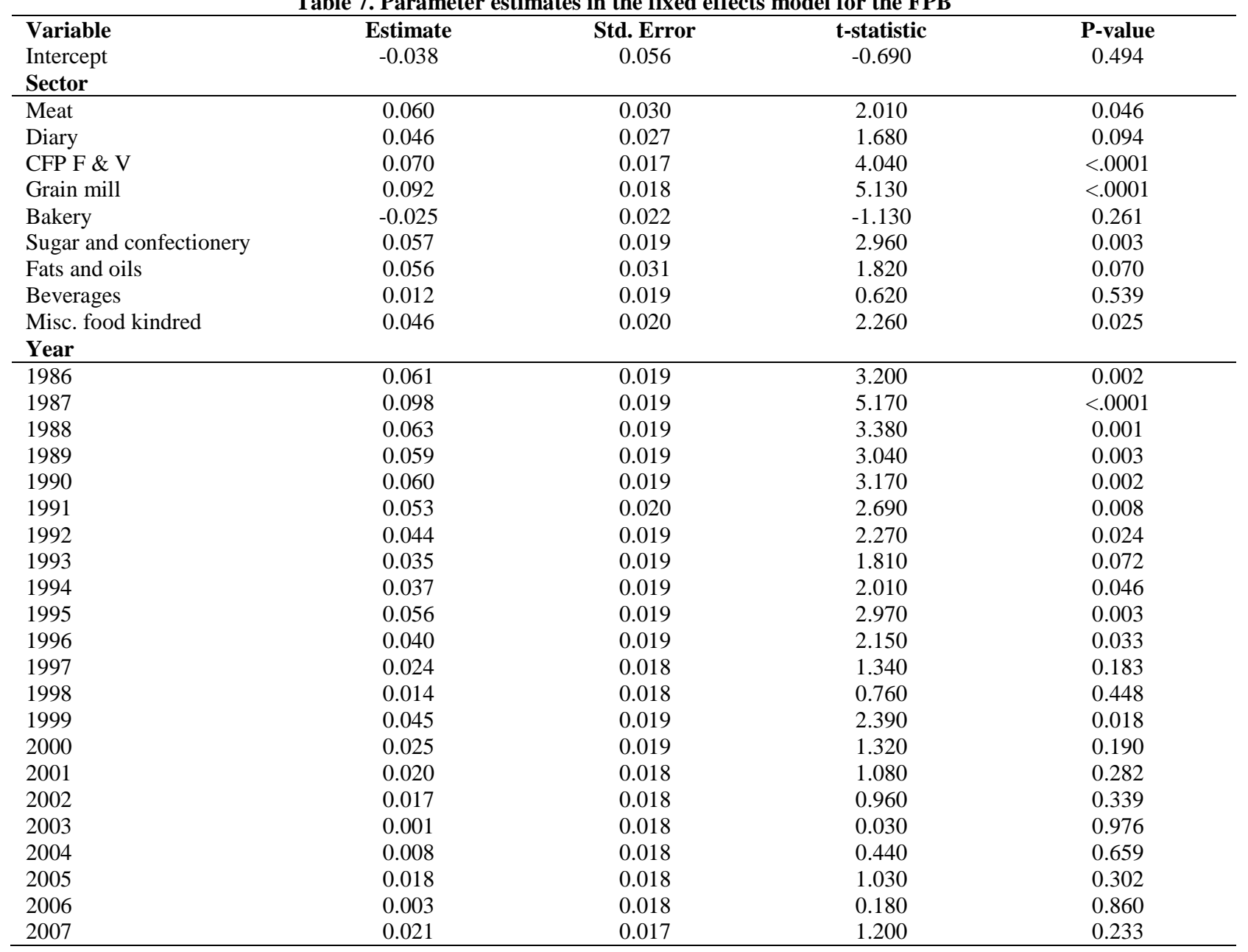


The two-way fixed-effects model output for the FWRS industry is provided in Table 8 . There are three cross sections (retailers, food wholesalers and food service) and the 23 time years from 1986 to 2008 . The F test for the two-way fixed effects shown in the Panel A provides evidence that there are no joint fixed effects. Likewise, results in Panel B indicate an absence of any sector effect and time effects. In essence, there is no statistical difference in accounting returns across sectors in FWRS over the past 23 years. The output of FWRS in the Table 9 corroborates this result. Six of the early years are significant, while the last 15 years are all not significant.

Table 8. Tests for the fixed cross-section and time effects in the FWRS industry

\begin{tabular}{|c|c|c|c|c|}
\hline \multicolumn{5}{|c|}{ Panel A : Fixed effect test } \\
\hline Model & Fixed effect & Sample Size & F Test & Prob value \\
\hline Two-way & $\begin{array}{l}\text { Both sectors and time: } \\
\mathrm{i}=540,514,581 \\
\mathrm{t}=1986,1987,1988 \ldots \ldots, 2008\end{array}$ & 69 & $\mathrm{~F}(24,33)=1.27$ & 0.2588 \\
\hline \multicolumn{5}{|c|}{ Panel B: Separate test for individual effect } \\
\hline Model & Fixed effect & Sample Size & F Test & Prob value \\
\hline One-way & Single sectors effect & 69 & $\mathrm{~F}(2,55)=1.57$ & 0.2167 \\
\hline One-way & Single time effect & 69 & $\mathrm{~F}(22,35)=1.21$ & 0.3079 \\
\hline
\end{tabular}

Table 9. Parameter estimates in the fixed effects model for FWRS industry

\begin{tabular}{|c|c|c|c|c|}
\hline Variable & Estimate & Std. Error & t-statistic & P-value \\
\hline Intercept & -0.141 & 0.211 & -0.670 & 0.510 \\
\hline \multicolumn{5}{|l|}{ Sector } \\
\hline Food store-retail & 0.151 & 0.176 & 0.860 & 0.398 \\
\hline Food wholesalers & 0.175 & 0.106 & 1.650 & 0.109 \\
\hline \multicolumn{5}{|l|}{ Year } \\
\hline 1986 & 0.092 & 0.067 & 1.360 & 0.182 \\
\hline 1987 & 0.116 & 0.067 & 1.740 & 0.090 \\
\hline 1988 & 0.129 & 0.050 & 2.590 & 0.014 \\
\hline 1989 & 0.153 & 0.052 & 2.970 & 0.006 \\
\hline 1990 & 0.179 & 0.056 & 3.200 & 0.003 \\
\hline 1991 & 0.123 & 0.047 & 2.650 & 0.012 \\
\hline 1992 & 0.083 & 0.039 & 2.130 & 0.041 \\
\hline 1993 & 0.061 & 0.039 & 1.550 & 0.132 \\
\hline 1994 & 0.052 & 0.043 & 1.220 & 0.232 \\
\hline 1995 & 0.030 & 0.036 & 0.840 & 0.407 \\
\hline 1996 & 0.024 & 0.036 & 0.660 & 0.511 \\
\hline 1997 & 0.009 & 0.032 & 0.270 & 0.789 \\
\hline 1998 & 0.015 & 0.034 & 0.430 & 0.670 \\
\hline 1999 & 0.009 & 0.031 & 0.310 & 0.762 \\
\hline 2000 & 0.008 & 0.031 & 0.270 & 0.790 \\
\hline 2001 & 0.020 & 0.028 & 0.730 & 0.468 \\
\hline 2002 & 0.023 & 0.028 & 0.830 & 0.410 \\
\hline 2003 & 0.001 & 0.029 & 0.030 & 0.976 \\
\hline 2004 & -0.018 & 0.029 & -0.630 & 0.533 \\
\hline 2005 & -0.010 & 0.030 & -0.320 & 0.749 \\
\hline 2006 & -0.012 & 0.030 & -0.410 & 0.683 \\
\hline 2007 & 0.011 & 0.027 & 0.420 & 0.680 \\
\hline
\end{tabular}

In summary, there are both sector and time effects in the FBP industry with regard to accounting returns. The within industry differences on returns imply that even though the ten sectors in this industry seem common they perform differently in terms of accounting returns. In addition, while returns change over time, these returns are not systematically affected by economic recessions, that is, FBP accounting returns have not been negatively affected by the three recent economic recessions. In contrast, no fixed effects are documented for the FWRS industry. The three sectors in this industry tend to perform in tandem. 


\section{CONCLUSIONS}

This study examines the U.S. agribusiness' profitability from 1986 to 2008. By using regression analysis, we model accounting returns as a function of diverse financial indicators. To select the explanatory variables we further decompose the DuPont equation and perform some ad hoc transformations to model return on investment (rather than return on equity). In addition, using a two-way fixed effects model, we test within sectors and time effects of returns. We compare time effects with the three most recent economic recessions (July 1990-March 1991, March-November 2001, and December 2007- still in progress as of 2011).

Our model explains at least $70 \%$ of variation (R squares of 0.72 and 0.80 for the FBP and FWRS industries respectively, statistically significant at $1 \%$ level). Most estimated parameters have the right sign. While the expected signs of profit margins factors (e.g., gross margin, and expenditures) seem obvious and probably worthless to be modeled, signs and magnitudes of asset turnover and leverage are more an empirical problem, especially the latter. While the signs of assets turnover could be explained (e.g., an increase in inventory turnover increases returns, and an increase in accounts receivable could decrease returns by the effect of uncollectible accounts), with the exception of PPE turnover, these parameters are no statistically significant. We believe that accounting returns in $t$ are probably not affected by the level of assets turnover as the DuPont equation predicts, but rather by the change from $t-1$ to $t$, which represents the improvement in asset usage efficiency. With regards to leverage, the traditional DuPont equation (1) shows that leverage should increase the return on equity, but cannot predict the effect on return on investment. Empirically, according to our model, long-term debt -but no short-term debt, negatively affects return on investment of agribusinesses.

In terms of the sector and time tests performed, the two industries have different results. Significant crosssection effects are present in the FPB industry. Returns are significantly different across sectors in that industry. However, the opposite is true for the FWRS' sectors returns because the cross-section effect is not significant.

We find both sector and time effects in the FBP industry with regard to accounting returns. The within industry differences on returns imply that even though the ten sectors in this industry seem common they perform differently in terms of accounting returns. In addition, while returns change over time, these returns are not systematically affected by economic recessions. That is, while there are significant time effects in the FPB, the fluctuation of accounting returns is not associated with recession periods, which indicates that there are other factors or reasons that are playing a more important role in the fluctuation of firm's profitability. In contrast, no fixed effects are documented for the FWRS industry. The three sectors in this industry tend to perform in tandem. Ultimately, this study concludes that accounting returns in the food supply chain are mainly affected by management operating strategy. Economic recessions do not have significant impact on profitability of the U.S. food supply chain statistically.

\section{AUTHOR INFORMATION}

Youshan Zhao is a graduate student in the Food and Resource Economics Department at University of Florida, U.S.A. Zhao has a background in accounting and statistics. She is a China Certified Public Accountant with industry experience in PricewaterhouseCoopers Beijing, China. E-mail: (youshan.ufl@gmail.com)

Carlos Omar Trejo-Pech is a Professor of Finance in the School of Business and Economics at Universidad Panamericana at Guadalajara, Mexico. He earned his Ph.D. from the University of Florida (2007). He has published articles in Journal of Financial Education, International Journal of Business and Finance Research, Agribusiness: An International Journal, among others. E-mail: ctrejo@up.edu.mx (Corresponding author)

Richard Weldon is a Professor of Agribusiness Finance in the Food and Resource Economics Department at University of Florida, U.S.A. He earned his Ph.D. in Agricultural and Applied Economics from the University of Minnesota, U.S.A. (1988). He has published several articles in the Agribusiness field. E-mail: rweldon@ufl.edu 


\section{REFERENCES}

1. Chaddad, F. \& Mondelli, M. (2010). Sources of firm performance differences in the U.S. food economy: exploring specific industry, corporate and business segment effects on agribusiness firm profitability. Selected Poster, Agricultural and Applied Economics Association 2010 Annual Meeting, Denver, Colorado. Retrieved from: http://ageconsearch.umn.edu/handle/61742

2. Fairfield, P., \& Yohn, T. (2003). Using Asset Turnover and Profit margin to Forecast Changes in Profitabilty. The Review of Accounting Studies, 6, 371-385.

3. Forster, D. (1996). Capital structure, business risk, and investor returns for agribusinesses. Agribusiness, An International Journal, 12, 429-442.

4. $\quad$ Greene, W. H. (2012). Econometric Analysis. 7th ed. Upper Saddle River: Prentice Hall.

5. Jensen, M. C. (1989). The eclipse of the public corporation. Harvard Business Review, 5, 61-74.

6. Schumacher, S. \& Boland M. (2005). The Persistence of Profitability among Firms in the Food Economy. American Journal of Agricultural Economics, 87 (1), 103-115

7. Neibergs, J. S. (1998). Macroeconomic Conditions and Agribusiness Profitability: An Analysis Using Pooled Data. International Food and Agribusiness Management Review, 1, 91-105.

8. Nissim, D. \& S.H. Penman (2001). Ratio analysis and equity valuation: From research to practice. Review of Accounting Studies, 6, 109-154.

9. Opler, T. C. \& Sheridan, T. (1994). Financial Distress and Corporate Performance. The Journal of Finance, 49, 1015-1040.

10. Selling, T., \& Stickney, C. (1989). The effects of business environments and strategy on a firm's rate of return on assets. Financial Analysts Journal , 45, 43-52.

11. Trejo-Pech, C. O., Weldon, R. N., \& House, L. A. (2008). Earnings, accruals, cash flows, and EBITDA for agribusiness firms. Agricultural Finance Review , 68, 301-319. 